\title{
Size and biomechanic properties of diatom frustules influence food uptake by copepods
}

\author{
L. Friedrichs ${ }^{1, *}$, M. Hörnig ${ }^{1}$, L. Schulze ${ }^{1}$, A. Bertram ${ }^{1}$, S. Jansen ${ }^{1}$, C. Hamm ${ }^{1,2}$ \\ ${ }^{1}$ Alfred-Wegener-Institute for Polar and Marine Research, Am Handelshafen 12, 27570 Bremerhaven, Germany \\ ${ }^{2}$ Institute for Marine Resources GmbH, Bussestr. 27, 27570 Bremerhaven, Germany
}

\begin{abstract}
Diatoms are encased within sophisticated stable lightweight silica cell walls. These frustules have the potential to protect the algal cell against the feeding tools of their most abundant metazoan predators, the copepods. We examined the mechanical strengths of the 3 North Sea diatom species Actinoptychus senarius, Thalassiosira punctigera and Coscinodiscus wailesii and their effect on feeding efficiency of copepods. (1) We determined the stability of the diatoms by means of 'micro-crush-tests' performed in the laboratory with calibrated microneedles. (2) In feeding experiments, we compared the ability and efficiency of the 3 North Sea copepod species Temora longicornis, Centropages hamatus and Acartia clausi to crush frustules. The results showed a remarkable correlation between mechanical properties and size of diatom frustules and feeding success of the copepods. The weakly silicified diatom T. punctigera was the least stable and best fed upon, whilst having the highest growth rate. The diatoms having the most complex frustule, A. senarius, exhibited the greatest stability, whilst being fed upon least. The largest diatom, C. wailesii, was partially protected by its size, but was nonetheless suitable as prey for the large copepods that, in the case of $C$. hamatus, seem to have developed special feeding techniques to overcome the size-mediated protection.
\end{abstract}

KEY WORDS: Diatoms · Copepods - Frustules · Functional morphology · Feeding experiments · Mechanical protection $\cdot$ Co-evolution

\section{INTRODUCTION}

Diatoms are unicellular algae, which contribute $\sim 40$ to $45 \%$ to marine primary production (Mann 1999) and strongly influence carbon and material fluxes in oceans (e.g. Smetacek 1999, Armbrust 2009). Furthermore, their most important grazers, the copepods, play an important role in such processes as they transfer diatom biomass to higher trophic levels and particulate matter, nutrients and carbon to the microbial loop, the deep sea, or even the sea floor. This transfer can take place either by sloppy feeding (Møller 2005) or faecal pellets (e.g. Turner \& Ferrante 1979, Bathmann et al. 1990, González \& Smetacek 1994, Smetacek 1999, Beaumont et al. 2002).
Prey organisms always develop defensive techniques, passive or active, chemical or structural to prevent being penetrated or grazed on. This applies to higher plants (Herms \& Mattson 1992, Moerschbacher \& Mendgen 2000, Boege \& Marquis 2005, Agrawal 2007, Hanley et al. 2007) as well as to macro-algae (Hay \& Fenical 1988, van Alstyne et al. 2001, Wright et al. 2004). The diatom's chemical defences have been discussed, e.g. by Pohnert (2000), Wolfe (2000), Paffenhöfer (2002) and Ianora et al. (2004) and have been shown to act indirectly and often with a time lag. In this work, we analyse the first line of defence, the mechanical protection provided by the silicified cell walls of diatoms, the frustules. 
The frustules of diatoms are very complex constructions. They consist mainly but not exclusively of amorphous silica and include silaffins, polyamines, frustulines, lipids and polysaccharides (Crawford et al. 2001, Falciatore \& Bowler 2002, Sumper \& Kröger 2004, Frigeri et al. 2006, Sumper \& Brunner 2008).

In microscopic analysis, uncountable features resembling modern stable lightweight structures are found in the diatom's frustules (Hamm 2005, Hamm \& Smetacek 2007). So both the material and the structure of diatoms contribute to their considerable strength. Besides the common structural design that all diatoms share ( 2 thecae overlapping each other to form an enclosure for the cell), the complexity in detail and the diversity of species is enormous and raises the question how and why these innumerable different features evolved.

An explanation can be found in an extended niches theory where predators graze on the inhabiting species. In a copepod-diatom co-evolution, the copepods adopt and evolve their feeding tools (Itoh 1970, Michels \& Schnack-Schiel 2005, Michels et al. 2012), whilst the diatoms modify and evolve their protecting frustules, ending in an arms race (Smetacek 2001, Hamm 2005, Hamm \& Smetacek 2007). This arms race changes the existing niches or even creates new ones, constantly fuelling evolutionary processes (van Valen 1973, Stenseth \& Smith 1984, Laland et al. 1999, Pearson 2001, Rausher 2001, Suzuki \& Arita 2005, Laland \& Boogert 2010).

The functional morphology of the feeding tools and feeding behaviour of copepods have been intensely studied in the present and past centuries, changing from a traditional view of copepods as pure filter feeders (Storch \& Pfisterer 1925, Cannon 1928) to selective feeders with the ability to adapt their feeding mode to the prey (e.g. Schnack 1989, Kiørboe et al. 1996). Technical advancements, especially the use of highspeed cameras, visualized the ability of copepods to detect and handle diatom cells with their feeding appendages in a 3-dimensional flow field (Bundy \& Vanderploeg 2002, Malkiel et al. 2003, Koehl 2004). The connection of the feeding tools' morphologies with physical properties of the preferred prey organisms has been investigated in several publications since the 1960s (Masateru \& Omori 1963, Itoh 1970, Turner 1978) and still spawns new results (Michels et al. 2012). On the other hand, studies on the significance of diatom frustules as armour against predators or mechanical environmental stresses are scarce in recent and past literature. The function of the diatom frustule, besides that of a boundary layer between surrounding medium and cell content (e.g. Round et al. 1990, Hale \& Mitchell 2001), is poorly understood. The analyses of micro- and nanostructured details (De Stefano et al. 2009), the description of internal stiffening elements to stabilize and protect the frustule against mechanical stresses (De Stefano et al. 2003) and studies on the protective function of the frustule against parasitoid protists (Kühn 1997) are instructive but lack a quantitative dimension.

In 1838, Christian Gottfried Ehrenberg described the frustule as a type of armour for diatoms (Ehrenberg 1838), thus implicating a protective function. Our work aims at the quantification of that protective function by postulating 3 hypotheses: (1) The armouring qualities of selected diatom species influence the feeding success of selected copepod species. (2) The mechanical protection of the diatom frustule excludes certain predators. (3) The feeding success of copepods is a function of the mechanical strength of diatom frustules.

In this work we examined these questions by means of feeding experiments conducted with copepods and diatom species that occur in the North Sea, and compared our findings with micro-crush tests in vitro with the same diatom species.

\section{MATERIALS AND METHODS}

\section{Diatom cultures}

Three monospecific cell cultures of the North Sea diatoms Thalassiosira punctigera, Coscinodiscus wailesii and Actinoptychus senarius were grown in f/2 medium according to Guillard \& Ryther (1962) in a $14 \mathrm{~h}$ light:10 h dark cycle, with light intensities of $350 \mu \mathrm{mol} \mathrm{m}{ }^{-2} \mathrm{~s}^{-1}$ at a temperature of $15^{\circ} \mathrm{C}$.

\section{Crush tests}

The tests were performed using 2 MPC-285 micromanipulators controlled by a ROE-200 controller unit (Sutter Instruments) equipped with 1 calibrated glass pipette for the force measurements and 1 uncalibrated pipette for the alignment of the specimen. For the force measurements, 9 microneedles were prepared by a P-97 micropipette puller (Sutter Instruments) by heating and pulling borosilicate glass pipettes of $100 \mathrm{~mm}$ length (outer diameter $1.0 \mathrm{~mm}$, inner diameter $0.5 \mathrm{~mm}$ ). The manufactured needles were bent in an angle of $\sim 22^{\circ}$ using a deFonbrune Microforge (H. Sauer) to fit the microscope set-up. The microneedles were subsequently calibrated by 
pressing their tips onto an AFM cantilever tip (NSC16/AIBS, $\mu$ Masch) with a known spring constant of $45 \mathrm{~N} \mathrm{~m}^{-1}$. The spring constant $(D)$ is defined by:

$$
D=F / \Delta L
$$

where $F$ is the force $(\mathrm{N})$ and $\Delta L$ is the deflection (m). The deflection of the tips is linear-proportional to the applied forces and allows the determination of the spring constants for the manufactured microneedles and, subsequently, the force that they exerted on the diatoms in the experiments. Needles with spring constants between 1 and $15 \mathrm{~N} \mathrm{~m}^{-1}$ were prepared. Needles with lower values were not able to break the diatoms' frustules, and higher spring constants resulted in needles too stiff to determine deflections in the experiments.

For the actual measurements, 1 diatom at a time was led and aligned to an edge formed by 2 coverslips (Fig. 1a), glued on top of each other and pressed against that edge with the calibrated microneedle. The process was filmed by a FASTCAM-X 1024 PCI high-speed camera (Photron Ltd.) at 1000 frames s$^{-1}$, with a resolution of $1024 \times 1024$ pixel. The deflection of the microneedle was measured on a still frame captured at the moment of breakage.

The diatom samples were crushed in 3 different orientations (Fig. 1b-d).

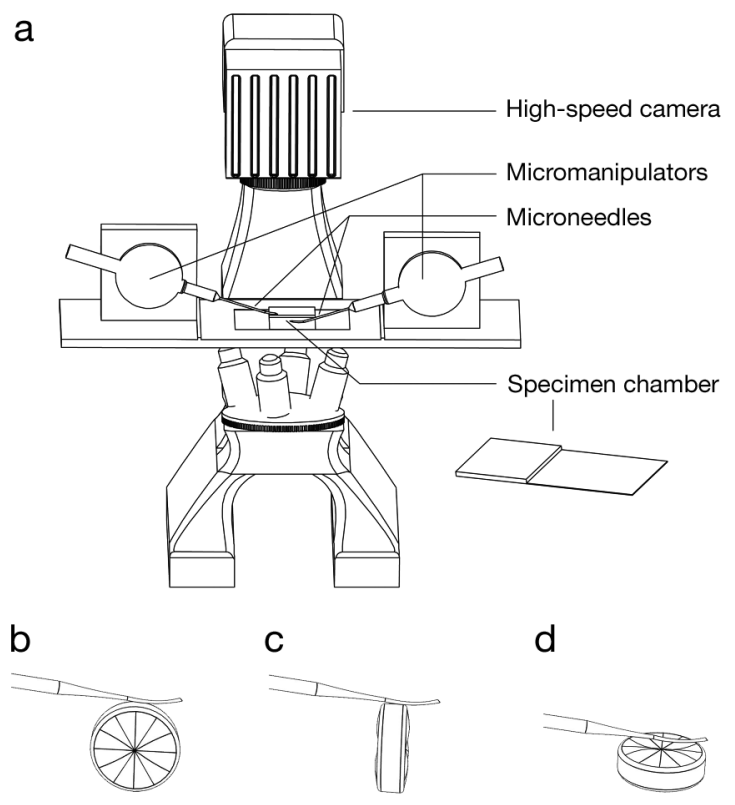

Fig. 1. (a) Experimental setup for the micro-crush tests. (b-d) Alignments of the diatom cells in the crush tests: (b) girdleband, (c) lateral, (d) valve

\section{Feeding experiments}

The same cultures of Actinoptychus senarius, Thalassiosira punctigera and Coscinodiscus wailesii from which diatoms were used for the crush tests were also utilized for the feeding experiments. Prior to the experiments, the cultures were transferred into 101 Nalgene bottles and allowed to grow for $2 \mathrm{wk}$.

In April 2009, 3 copepod species were collected with plankton nets at the permanent sampling station Helgoland Roads $\left(54^{\circ} 11^{\prime} \mathrm{N}, 7^{\circ} 54^{\prime} \mathrm{E}\right)$ : Temora longicornis and Centropages hamatus (500 $\mu \mathrm{m}$ mesh) and the smaller species, Acartia clausi $(280 \mu \mathrm{m})$. A. clausi, T. longicornis and C. hamatus are very common, even dominant calanoid copepods in the North Sea, predominantly occurring in surface waters (Hickel 1975, Fransz et al. 1991). T. longicornis and $A$. clausi are present all year round at Helgoland Roads (Halsband \& Hirche 2001, Halsband-Lenk et al. 2004). In contrast, C. hamatus is present only from March to November, with highest abundances from June to August.

The prosome lengths of female Temora longicornis range from 726 to $1360 \mu \mathrm{m}$, with the largest individuals in spring. Prosome length of adult female Centropages hamatus varies from 750 to $1570 \mu \mathrm{m}$, with the largest individuals present from April to June (Halsband-Lenk et al. 2004). Acartia clausi is the smallest of the 3 species, with prosome lengths of 650 to $1140 \mu \mathrm{m}$; the largest specimens occur in June (Halsband \& Hirche 2001).

All 3 species are known to be omnivorous (Masateru \& Omori 1963, Conley \& Turner 1985, Kleppel 1993, Dam \& Lopes 2003).

For each experiment, 20 healthy female Temora longicornis and Centropages hamatus and 100 Acartia clausi were chosen and transferred into 11 beakers with filtered seawater. Diatom concentrations were adjusted to $800 \mu \mathrm{g} \mathrm{Cl}^{-1}$, providing unlimited food for the copepods (Vidal 1980, Koski \& Klein Breteler 2003). The starting concentrations were 1400 cells ml ${ }^{-1}$ for Thalassiosira punctigera diets, 95 cells ml $\mathrm{ml}^{-1}$ for Actinoptychus senarius diets and 60 cells ml $^{-1}$ for Coscinodiscus wailesii diets.

The feeding experiments were conducted in duplicates. The cell counts were conducted in triplicates. Experiments in 8 different pairings (Table 1) plus 1 control for each diatom species without copepods were carried out for $48 \mathrm{~h}$; the diatom cells were gently agitated in $2 \mathrm{~h}$ intervals (daytime) to $4 \mathrm{~h}$ intervals (night-time).

After $24 \mathrm{hs}$, the first samples $(20 \mathrm{ml}$ each) were taken from each bottle and 3 subsamples were 
Table 1. Combinations of feeding experiments. T. p.: Thalassiosira punctigera, A. s.: Actinoptychus senarius, C. w.: Coscinodiscus wailesii

\begin{tabular}{|lccc|}
\hline \multirow{2}{*}{ Copepod species } & \multicolumn{3}{c|}{ Diatom species } \\
\cline { 2 - 4 } & T.p. & A. s. & C. $w$. \\
\hline Acartia clausi & + & + & + \\
Centropages hamatus & + & No data & + \\
Temora longicornis & + & + & + \\
\hline
\end{tabular}

counted. Simultaneously, another $20 \mathrm{ml}$ without grazers was taken from each experiment bottle and put aside to act as controls for the following sampling taken after another $24 \mathrm{~h}$.

The ingestion rate $(I)$ was calculated according to Esaias \& Curl (1972):

$$
I=\frac{\left(C_{c}-C_{g}\right) \cdot V}{N \cdot t}
$$

where $C_{\mathrm{c}}$ is the cell concentration in the control bottle, $C_{\mathrm{g}}$ is the cell concentration in the grazed bottle, $N$ is the number of copepods, $V$ is the volume of the bottles and $t$ is the time in hours.

The bottles were kept dark during the experiments to prevent diatom growth. All samples for counting were preserved with 4 drops of borax-buffered $40 \%$ formalin and counted in triplicate using an inverted Zeiss Axiomat microscope. Material not used for counting was preserved and filtered with a $20 \mu \mathrm{m}$ mesh. Faecal pellets were picked from the filtrate and washed 5 times along with the remaining diatoms with deionized water, mounted on coverslips and calcined with a Bunsen burner to eliminate the organic contents of the sample. The prepared coverslips were mounted for scanning electron microscopy with carbon sticky tabs and sputter-coated with gold and palladium. Subsequently, the stubs were mounted in a FEI Quanta 200 FEG scanning electron microscope (SEM) and imaged at an accelerating voltage of $10 \mathrm{kV}$.

\section{Statistics}

To determine the statistically significant differences of the crush tests, a 1-way analysis of variance (ANOVA) was performed for each species, comparing the 3 different orientations. A Shapiro-Wilk normality test verified the normal distribution of the data. The cell ingestion rates of Coscinodiscus wailesii and Thalassiosira punctigera failed the ShapiroWilk normality test and were hence tested by a 1- way ANOVA on ranks (Kruskal-Wallis test). The cell ingestion rates of Actinoptychus senarius were tested by a $t$-test, because only 1 pair had to be compared. Carbon ingestion rates of $A$. senarius were tested by a Mann-Whitney rank sum test, because only 2 sample sets had to be tested; the carbon ingestion rates of the other 2 species were analysed by a 1-way ANOVA on ranks (Kruskal-Wallis test). The data were not normally distributed in any of the 3 cases. The significance level for all tests was $p<0,05$. Statistical calculations were performed by SigmaPlot 11 (Systat Inc.).

\section{RESULTS}

\section{Crush tests}

Actinoptychus senarius exhibits the strongest frustule in all 3 orientations. Large cells resisted on average $>700 \mu \mathrm{N}$, while small cells crushed at $<600 \mu \mathrm{N}$. This corresponds very well to the apparent compactness of the frustule. The mean forces needed to crush the frustule of $A$. senarius did not differ significantly, no matter how the cells were aligned for the crush test ( $p>0.05$; Fig. 2a,b), but the large cells showed significantly higher stabilities than the small ones ( $\mathrm{p}<0.001, t$-test). This is particularly interesting as the large cells are supposed to be less stable than small.

Unlike Actinoptychus senarius, the alignment of the diatom Coscinodiscus wailesii resulted in significant differences. The forces necessary to break the girdle band region were significantly lower $(\mathrm{p}<$ 0.001, 1-way ANOVA) than the forces for the other 2 alignments (lateral and valve; Fig. 2c). The absolute values were somewhat lower than those of the small A. senarius cells (Table 2), resulting in a lower overall stability of this species.

Cells of Thalassiosira punctigera break at comparable forces to those of Coscinodiscus wailesii, being most stable for lateral force and significantly weaker in the other 2 directions ( $<<0.05,1$-way ANOVA) (Fig. 2d).

\section{Feeding experiments}

To test the influence of the diatom's mechanical stability on the feeding success of copepods, 3 different diatoms were fed to the North Sea copepods Acartia clausi, Temora longicornis and Centropages hamatus. The highest ingestion rates were measured 


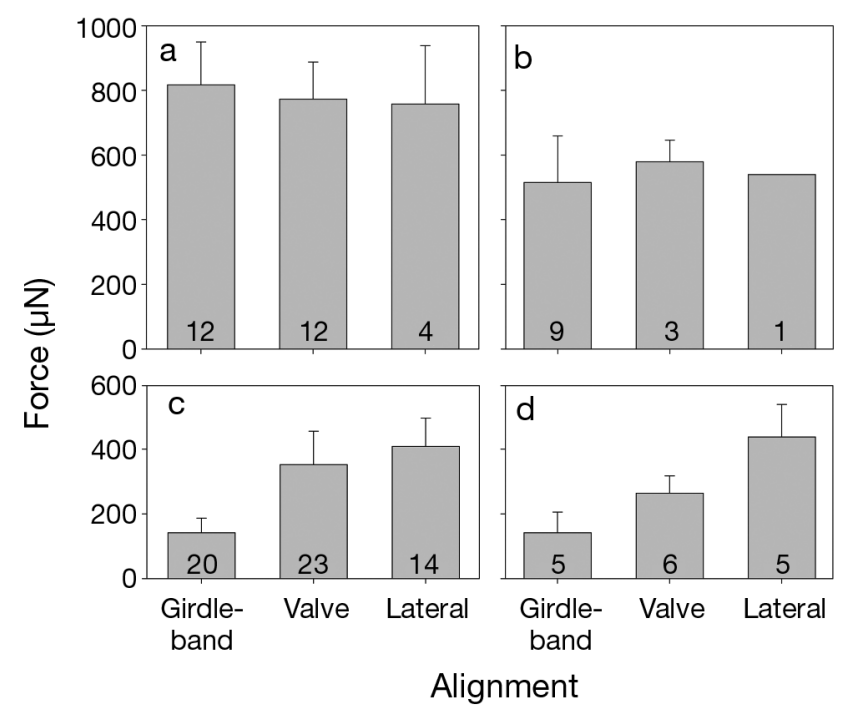

Fig. 2. Applied forces before crush of the frustules of (a) Actinoptychus senarius, large cells, ca. $125 \mu \mathrm{m}$ diameter, (b) A. senarius, small cells, ca. $55 \mu \mathrm{m}$, (c) Coscinodiscus wailesii, ca. $110 \mu \mathrm{m}$ and (d) Thalassiosira punctigera ca. $60 \mu \mathrm{m}$. Means + SD, n: given as figure in column

Table 2. Forces $(\mu \mathrm{N})$ necessary to break Actinoptychus senarius (ca. 55 and $125 \mu \mathrm{m}$ diameter), Coscinodiscus wailesii (ca. $110 \mu \mathrm{m})$ and Thalassiosira punctigera $(60 \mu \mathrm{m})$ in different alignments. Means $\pm \mathrm{SD}$

\begin{tabular}{|lccc|}
\hline & Girdleband & \multicolumn{1}{c|}{ Valve } & Lateral \\
\hline $\begin{array}{l}\text { A. senarius } \\
\text { (large) }\end{array}$ & $817.5 \pm 132.0$ & $772.7 \pm 114.8$ & $757.8 \pm 181.1$ \\
$\begin{array}{c}\text { A. senarius } \\
\text { (small) }\end{array}$ & $514.9 \pm 144.5$ & $579.5 \pm 66.7$ & $540.0 \pm 0.0$ \\
$\begin{array}{l}\text { C. } \text { wailesii } \\
\text { T. punctigera }\end{array}$ & $141.9 \pm 45.0$ & $352.3 \pm 103.9$ & $408.6 \pm 88.0$ \\
\hline
\end{tabular}

the large (A. senarius and C. wailesii) and the small algae (Thalassiosira punctigera) ( $\mathrm{p}<0.05$, ANOVA on ranks).

To evaluate the nutrient-relevant content, these cell counts were converted into carbon values (using the factor by Strathmann 1967), resulting in a carbon content of $8394 \mathrm{pg} \mathrm{C}$ cell $^{-1}$ for Actinoptychus senarius, $980 \mathrm{pg} \mathrm{C}$ cell $^{-1}$ for Thalassiosira punctigera and 22723 pg C cell ${ }^{-1}$ for Coscinodiscus wailesii. Evidently the ingested amount of carbon (Fig. 3b) of the small T. punctigera cells equals to the amount ingested as large $C$. wailesii cells ( $\mathrm{p}>0.05$, ANOVA on ranks). By consumption of the cells of A. senarius, in contrast to the other 2 diatom species, all copepods gained significantly less carbon on that diet $(\mathrm{p}<0.05$, ANOVA on ranks).

\section{DISCUSSION}

Precise quantification of the effectiveness of biomechanical protection against grazers by the silica frustule is hard to show in field experiments. The variability of many factors in the field is very high such as the fitness of grazers, unknown or unmeasured types of chemical protection, side effects of sampling, the history of predators and prey, or a combination of the above. However, the results of these combined experiments indicated strongly that there are differences in frustule stability, as well as in defensive strategies, in the examined diatom species.

Whilst Coscinodiscus wailesii and Thalassiosira punctigera (although like all diatom frustules complex in their fractal-built fine structure) are simply 'petri-box'-shaped in their overall geometry, Actino- with the smallest algae, Thalassiosira punctigera (Fig. 3a). Feeding rates of $\sim 1000$ cells per copepod and hour were observed, a rate that was also achieved without significant differences by A. clausi, T. longicornis and C. hamatus ( $p>0.05$, ANOVA on ranks).

Approximately 100 times lower feeding rates were observed for the larger cells of Coscinodiscus wailesii and Actinoptychus senarius, again without significant differences between the consuming copepod species $(\mathrm{p}>0.05$, ANOVA on ranks and $t$-test, respectively), but constituting a significant difference between the ingestion rates for
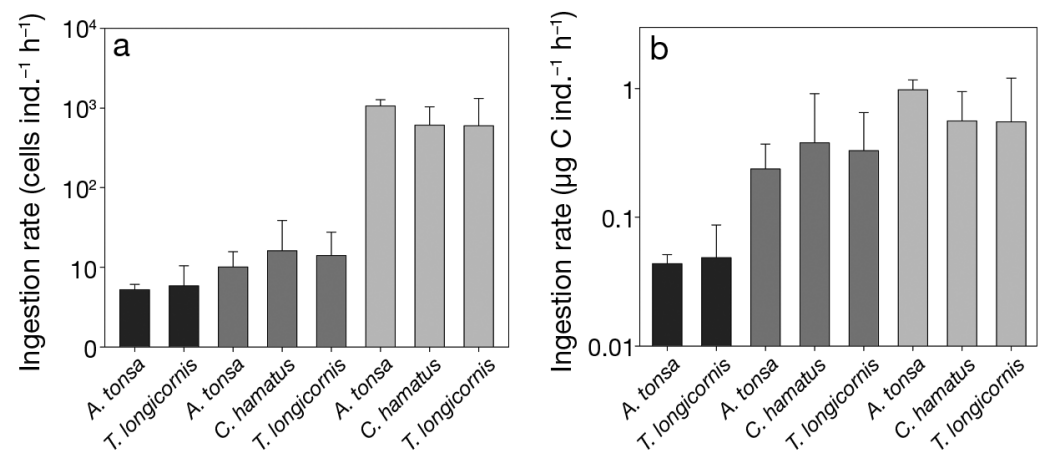

Fig. 3. Ingestion rates of (a) cells and (b) carbon for 3 copepod species (Acartia clausi, Centropages hamatus, Temora longicornis) feeding on 3 diatom species (black: Actinoptychus senarius; dark grey: Coscinodiscus wailesii; light grey: Thalassiosira punctigera) 
ptychus senarius features an additional tier, in the form of a wavelike undulated surface geometry. This additional feature, along with a more structured and detailed surface texture, increases the level of complexity in this species.

By taking the growth rates (Table 3 ) of the diatoms into account, 3 strategies could be identified: Thalassiosira punctigera grew fastest and developed high cell numbers in culture, but exhibited relatively thin and not very complex frustules, which were easily ingested by the copepods. Coscinodiscus wailesii and Actinoptychus senarius pursued a different strategy: both of them grew much more slowly than T. punctigera. While A. senarius formed frustules of high complexity, C. wailesii invested energy in cell size which can reach $500 \mu \mathrm{m}$ in diameter (Edwards et al. 2001).

All these 3 strategies are plausible. (1) High cell numbers compensate for high feeding rates. (2) Large cell sizes increase the potential of 'size escape' and are generally not preferred by predators, as large sizes increase 'sloppy feeding' (Roy et al. 1989, Møller 2005, Jansen 2008). (3) Massive and complex frustule geometries result in high mechanical resilience. If the grazers' feeding tools are not capable of exerting enough force to crack the frustules, it is possible that viable cells within intact frustules may be found in faecal pellets (Fowler \& Fisher 1983, Kuwata \& Tsuda 2005, Jansen \& Bathmann 2007).

The 3 strategies are also mirrored in Fig. $4 \mathrm{a}$, resulting in a picture of cascading steps: the highest ingestion rates are achieved by all copepods on the least silicified diatom, Thalassiosira punctigera. Although of comparably low stability as T. punctigera, Coscinodiscus wailesii is ingested to a much lesser extent in our biomechanical approach due to its larger size. Yet fewer cells are ingested of the most stable species, Actinoptychus senarius. The growth rates (Fig. 4a, dotted lines) follow exactly the same trends, supporting the previously proposed hypotheses.

For copepods the nutritious content is most essential; here expressed as carbon content (Figs. 3b $\& 4 \mathrm{~b})$. The ingestion of many fewer, but very large Coscinodiscus wailesii cells, sums up to a comparable amount of carbon gained by feeding on a large number of Thalassiosira punctigera cells (Fig. 3b).
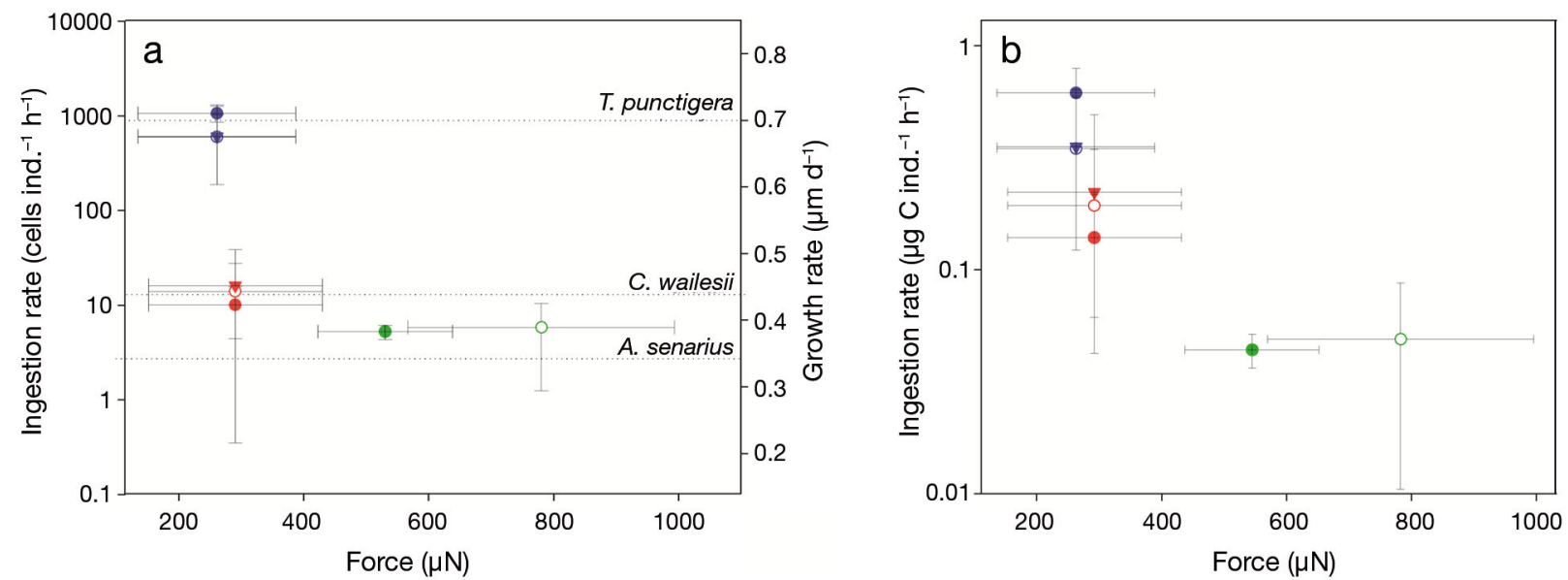

Fig. 4. Ingestion rates of (a) cells and (b) carbon versus mean crushing forces. Ingestion rates correspond to Fig. 3, the forces are means \pm SD from all 3 alignments and correspond to the values in Fig. 2. Copepods: $\bullet=$ Acartia clausi; $\bigcirc=$ Temora longicornis $; \boldsymbol{\nabla}=$ Centropages hamatus; diatoms: blue = Thalassiosira punctigera $;$ red = Coscinodiscus wailesii $;$ green $=$ Actinoptychus senarius; dotted lines: growth rates of the diatoms

Table 3. Characteristic values of the diatoms used in the feeding experiments. Diameter and height are means; growth rates are given for exponential growth. Biovolume, surface area and surface to volume (S:V) ratio were calculated with assistance of the software BIOVOL 2.1 (Kirschtel 1996), with the basic formula for cylindrical shapes

\begin{tabular}{|lccccccc|}
\hline Taxon & $\begin{array}{c}\text { Diameter } \\
(\mu \mathrm{m})\end{array}$ & $\begin{array}{c}\text { Height } \\
(\mu \mathrm{m})\end{array}$ & $\begin{array}{c}\text { Biovolume } \\
\left(\mu \mathrm{m}^{3}\right)\end{array}$ & $\begin{array}{c}\text { Surface area } \\
\left(\mu \mathrm{m}^{2}\right)\end{array}$ & $\begin{array}{c}\text { S:V } \\
\text { ratio }\end{array}$ & $\begin{array}{c}\text { Diameter: } \\
\text { Height ratio }\end{array}$ & $\begin{array}{c}\text { Growth rate } \\
\left(\mu \mathrm{m} \mathrm{d}^{-1}\right)\end{array}$ \\
\hline Actinoptychus senarius & 133 & 38.5 & $5.36 \times 10^{5}$ & 43893 & 0.082 & 3.450 & 0.344 \\
Coscinodiscus wailesii & 160 & 88 & $2.10 \times 10^{6}$ & 92795 & 0.046 & 1.818 & 0.441 \\
Thalassiosira punctigera & 40 & 26 & $2.94 \times 10^{4}$ & 5677 & 0.178 & 1.538 & 0.699 \\
\hline
\end{tabular}


The question whether feeding on a few large $C$. wailesii cells or many small $T$. punctigera cells is energetically preferable cannot be answered here. The feeding traces on diatom frustules (Fig. 5) indicated that copepods were able to break the frustules, but they provide no information on the carbon content actually absorbed. As indicated by Møller \& Nielsen (2001), a large prey relative to the size of the copepod results in a larger amount of lost material than that indicated by clearing experiments ('sloppy feeding'). We can state that Actinoptychus senarius, with its complex and stable frustule, does not nourish copepods as well as diatoms with less complex frustules (Figs. 3b \& 4b) and will presumably be avoided if a different food source is available. Selective feeding according to food quality has been examined in several studies (Paffenhöfer 1971, 1976, Paffenhöfer \& Van Sant 1985, Cowles et al. 1988, Mayzaud et al. 1998, Kuwata \& Tsuda 2005). While nutrient composition has an effect on selective feeding, the availability of this content being protected by a mechanical barrier has not yet been taken into account.

As shown by Jansen (2008), copepods develop sophisticated techniques to overcome this barrier without losing cell contents by sloppy feeding. The copepod Temora longicornis takes bites out of pieces of the frustule of large diatoms to ingest cell contents. SEM analysis of cells of Coscinodiscus wailesii from cultures, on which Centropages hamatus had fed, led us to the assumption that an analogous feeding technique exists. The girdlebands, already identified as the weakest part of the diatom's frustule (Fig. 2c), showed typical recurring holes (Fig. 6a,b), which were most probably caused by the copepod's feeding behaviour on large cells (ca. 120 to $150 \mu \mathrm{m}$ diameter). The smaller cells (Fig. 5f) showed more common fractures and explain the bits and pieces of the diatom frustules found in the fae-

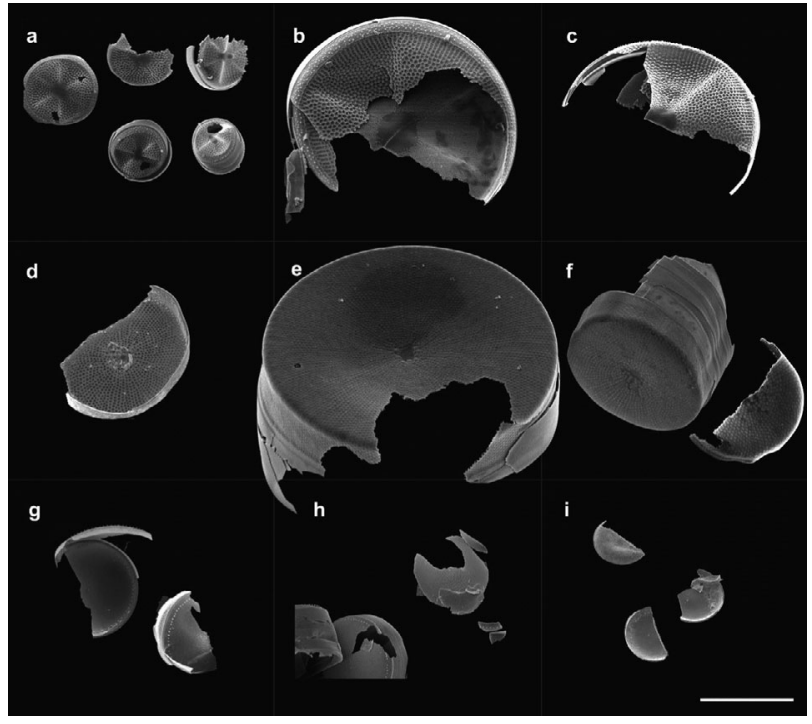

Fig. 5. Representative feeding traces on diatom frustules. $(\mathrm{a}-\mathrm{c})$ Copepods feeding on Actinoptychus senarius: Acartia clausi (a), Temora longicornis (b), Centropages hamatus (c). (d-f) Copepods feeding on Coscinodiscus wailesii: A. clausi (d), T. longicornis (e), C. hamatus (f). (g-i) Copepods feeding on Thalassiosira puncitgera: A. clausi (g), T. longicornis (h), C. hamatus (i). Scale bar $=50 \mu \mathrm{m}$

cal pellets in addition to the fragments of girdlebands (Figs. 6c \& 7)

Feeding traces of Temora longicornis on Coscinodiscus wailesii (Fig. 5e) were very much as described by Jansen (2008) and not notably different from their traces on Actinoptychus senarius and Thalassiosira punctigera (Fig. 5b,h).

The smaller copepod Acartia clausi was able to feed on all 3 diatom species, but the microscopic examination attested to feeding marks only on the small size fraction of the diatom culture (compare Fig. 5a,d,g). Here, the downsizing vegetative division mode of diatoms enables small predators to feed on these species.
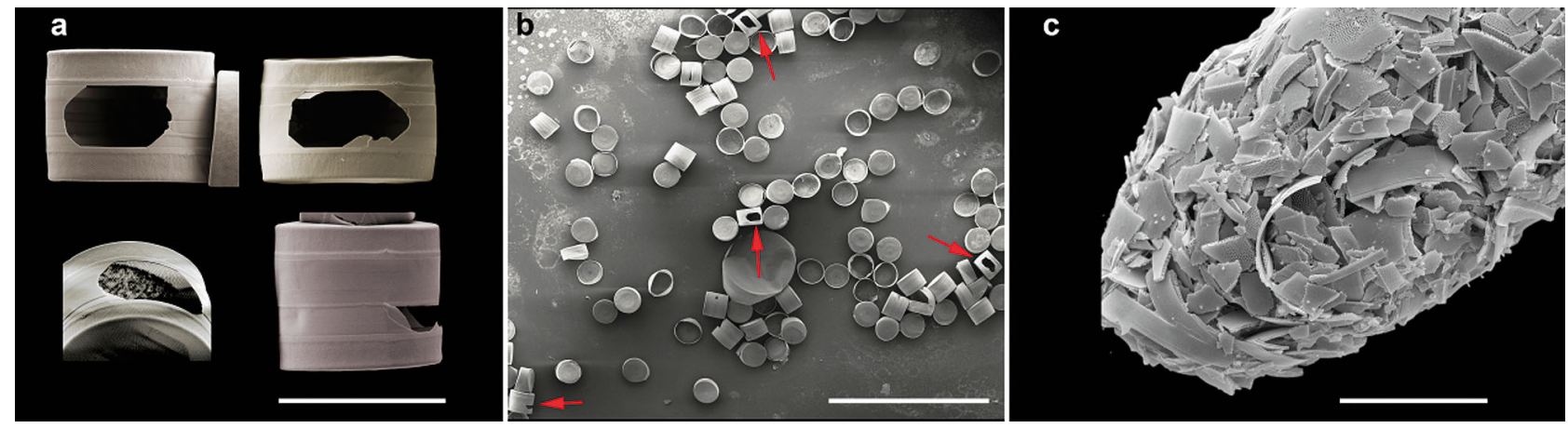

Fig. 6. Coscinodiscus wailesii. (a,b) Cells after being fed on by Centropages hamatus and (c) corresponding faecal pellet. Scale bars $=$ (a) $150 \mu \mathrm{m}$, (b) $1000 \mu \mathrm{m}$, (c) $25 \mu \mathrm{m}$ 


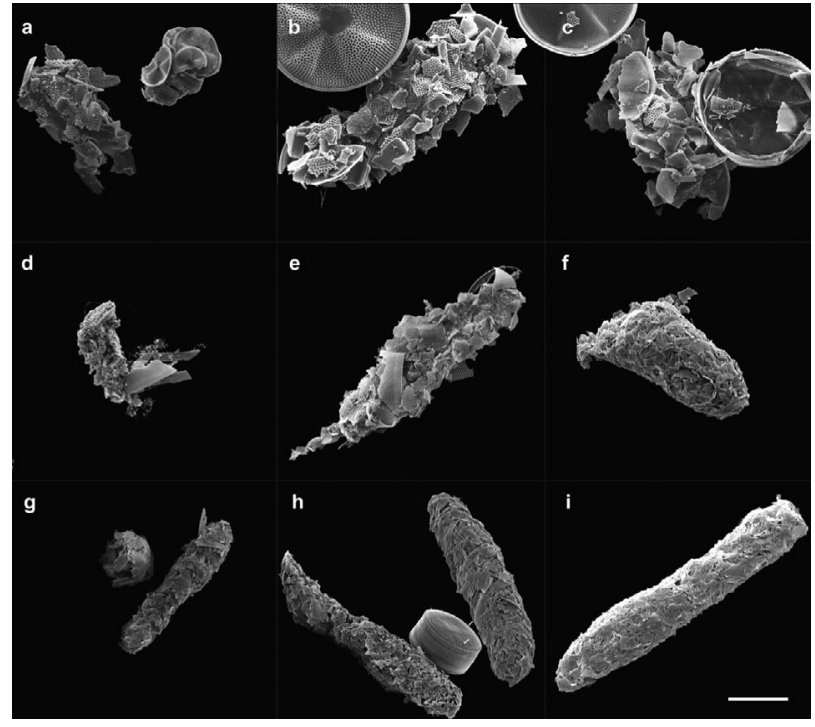

Fig. 7. Representative faecal pellets. (a-c) Copepods feeding on Actinoptychus senarius: Acartia clausi (a), Temora longicornis (b), Centropages hamatus (c). (d-f) Copepods feeding on Coscinodiscus wailesii: A. clausi (d), T. longicornis (e), C. hamatus (f). (g-i) Copepods feeding on Thalassiosira puncitgera: A. clausi (g), T. longicornis (h), C. hamatus (i). Scale bar $=50 \mu \mathrm{m}$
All 3 copepod species are omnivorous (Kiørboe et al. 1982, Kleppel 1993, Dam \& Lopes 2003, Pagano et al. 2003, Katechakis et al. 2004) and exhibit the corresponding mandibular gnathobases (Fig. 9) and express short and compact teeth that provide the required stability to crack and mince even the frustules of diatoms (Masateru \& Omori 1963, Itoh 1970, Sullivan et al. 1975, Michels \& Schnack-Schiel 2005). The gnathobase is the copepod's tool for mincing cells prior to ingestion and acts as the mechanical antagonist of the diatom frustules. Besides the silica enforcement of the tooth-like structures, recent findings show an elastic layer of resilin, which is considered to improve stability against mechanical damage when feeding on hard and stiff structures like diatom frustules (Michels et al. 2012). These findings are supported by our results: the copepods were able to exert very great forces (>700 $\mu \mathrm{N}$, cf. Fig. 2) and managed to crush even the stable frustules of Actinoptychus senarius.

The ingestion rate, gut passage time and egestion rate that influence faecal pellet production vary as a function of several factors, e.g. temperature, feeding activity and food concentrations (e.g Kiørboe et al. 1982, Dagg \& Wyman 1983, Baars \& Oosterhuis 1984). Decreasing food concentrations reduce faecal pellet production and lead to smaller pellets (Dagg \& Walser 1986, 1987), while the effect of food concentration and food quality on the density of the faecal pellets is controversial (Bienfang 1980, Dagg \& Walser 1987, Butler \& Dam 1994, Feinberg \& Dam 1998, Besiktepe \& Dam 2002). However, frustule stability seems to have an effect on pellet density in our experiments, possibly due to the low ingestion rate (Besiktepe \& Dam 2002). The egested Actinoptychus senarius pieces in faecal pellets (Fig. $7 \mathrm{a}-\mathrm{c}$ ) were notably less densely packed than those of Thalassiosira punctigera (Fig. $7 \mathrm{~g}-\mathrm{i}$ ). Whether this difference was due to the low ingestion rate or the inability to break the textured surface of $A$. senarius into smaller pieces is unknown. Pellet density affects sinking rates (Small et al. 1979, Komar et al. 1981), so material transport is not only influenced by the quantity of ingestible food and the quantity of food actually ingested, but also by the quality of the egested cell fragments. SEM analysis confirmed
Fig. 9. Gnathobases of (a) Temora longicornis, (b) Centropages hamatus and (c) Acartia clausi. Scale bar $=20 \mu \mathrm{m}$ 
observations of feeding marks; all copepod species fed on all diatoms, and fragments of the frustules were found in all faecal pellets.

The crush tests indicated that the frustules of Actinoptychus senarius, unlike those of Thalassiosira punctigera and Coscinodiscus wailesii, lack a soft spot at the girdle bands (Fig. 2), although they have a similar principal construction and hence are expected to exhibit similar weaknesses. While the mean cell size of a population decreases during vegetative reproduction (Fig. 8a), neither the silica patterns, nor frustule thickness change to the same extent (Fuhrmann et al. 2004, Hamm \& Smetacek 2007). A constant frustule thickness with decreasing cell size has a positive effect on the stability of smaller cells, as shown by Hamm et al. (2003) for T. punctigera. The more complex geometry of $A$. senarius reverses this trend, although patterning and frustule thickness do not change, but the amplitude of the main mould (peak-to-peak distance of the segments of 1 valve) increases with cell size (Fig. 8b). The cells of this species are more stable at larger sizes and therefore benefit from 2 anti-grazing strategies: excluding small grazers ('size escape') and being very stable due to the topography of the cells.

\section{CONCLUSIONS}

Our experiments have shown that the mechanical properties of the frustules of 3 widely abundant diatoms differ fundamentally. Actinoptychus senarius has a compact frustule with undulated valves and a small girdleband surface. This diatom can withstand high forces and does not have an apparent flaw in its mechanical defence. Thalassiosira punctigera and Coscinodiscus wailesii are more simple ('pillbox') shaped, with more-or-less plain valves and a larger girdleband surface. This girdleband area is the weakest point of the frustule. These results are consistent with feeding strategies and feeding rates of the 3 copepod species used in the experiments. They show that sizes, weak regions and overall mechanical strengths can be decisive factors for the ability and efficiency of copepods to feed on diatoms.

Acknowledgements. We thank Friedel Hinz for sample preparation and SEM support, as well as Alexandra Kraberg and the staff of the Biological Institute Helgoland (BAH) for supporting the experiments. This work was funded by the virtual institute 'PlanktonTech' of the Helmholtz Society.

\section{LITERATURE CITED}

Agrawal AA (2007) Macroevolution of plant defense strategies. Trends Ecol Evol 22:103-109

Armbrust EV (2009) The life of diatoms in the world's oceans. Nature 459:185-192

> Baars MA, Oosterhuis SS (1984) Diurnal feeding rhythms in North Sea copepods measured by gut fluorescence, digestive enzyme activity and grazing on labelled food. Neth J Sea Res 18:97-119

Bathmann UV, Peinert R, Noji TT, Bodungen BV (1990) Pelagic origin and fate of sedimenting particles in the Norwegian Sea. Prog Oceanogr 24:117-125

Beaumont KL, Nash GV, Davidson AT (2002) Ultrastructure, morphology and flux of microzooplankton faecal pellets in an east Antarctic fjord. Mar Ecol Prog Ser 245:133-148

Besiktepe S, Dam HG (2002) Coupling of ingestion and defecation as a function of diet in the calanoid copepod Acartia tonsa. Mar Ecol Prog Ser 229:151-164

$>$ Bienfang PK (1980) Herbivore diet affects fecal pellet settling. Can J Fish Aquat Sci 37:1352-1357

> Boege K, Marquis RJ (2005) Facing herbivory as you grow up: the ontogeny of resistance in plants. Trends Ecol Evol 20:441-448

Bundy MH, Vanderploeg HA (2002) Detection and capture of inert particles by calanoid copepods: the role of the feeding current. J Plankton Res 24:215-223

> Butler M, Dam HG (1994) Production rates and characteristics of fecal pellets from the copepod Acartia tonsa under simulated phytoplankton bloom conditions: implications for vertical fluxes. Mar Ecol Prog Ser 114:81-91

Cannon HG (1928) On the feeding mechanism of the copepods, Calanus finmarchicus and Diaptomus gracilis. J Exp Biol 6:131-144

> Conley WJ, Turner JT (1985) Omnivory by the coastal marine copepods Centropages hamatus and Labidocera aestiva. Mar Ecol Prog Ser 21:113-120

> Cowles TJ, Olson RJ, Chisholm SW (1988) Food selection by copepods: discrimination on the basis of food quality. Mar Biol 100:41-49

Crawford SA, Higgins MJ, Mulvaney P, Wetherbee R (2001) Nanostructure of the diatom frustule as revealed by atomic force and scanning electron microscopy. J Phycol 37:543-554

> Dagg MJ, Walser WEJ (1986) The effect of food concentration on fecal pellet size in marine copepods. Limnol Oceanogr 31:1066-1071

> Dagg MJ, Walser WEJ (1987) Ingestion, gut passage, and egestion by the copepod Neocalanus plumchrus in the laboratory and in the subarctic Pacific Ocean. Limnol Oceanogr 32:178-188

> Dagg MJ, Wyman KD (1983) Natural ingestion rates of the copepods Neocalanus plimcrus and N. cristatus calculated from gut contents. Mar Ecol Prog Ser 13:37-46

> Dam HG, Lopes RM (2003) Omnivory in the calanoid copepod Temora longicornis: feeding, egg production and egg hatching rates. J Exp Mar Biol Ecol 292:119-137

> De Stefano M, Kooistra WHCF, Marino D (2003) Morphology of the diatom genus Campyloneis (Bacillariophyceae, Bacillariophyta), with a description of Campyloneis juliae sp. nov. and an evaluation of the function of the Valvocopulae. J Phycol 39:735-753

$>$ De Stefano M, De Stefano L, Congestri R (2009) Functional morphology of micro- and nanostructures in two distinct diatom frustules. Superlattices Microstruct 46:64-68 
Edwards M, John AWG, Johns DG, Reid PC (2001) Case history and persistence of the non-indigenous diatom Coscinodiscus wailesii in the north-east Atlantic. J Mar Biol Assoc UK 81:207-211

Ehrenberg CG (1838) Die Infusionsthierchen als vollkommene Organismen. Ein Blick in das tiefere organische Leben der Natur. L. Voss, Leipzig

Esaias WE, Curl HC Jr (1972) Effect of dinoflagellate bioluminescence on copepod ingestion rates. Limnol Oceanogr 17:901-906

Falciatore A, Bowler C (2002) Revealing the molecular secrets of marine diatoms. Annu Rev Plant Biol 53: 109-130

Feinberg LR, Dam HG (1998) Effects of diet on dimensions, density and sinking rates of fecal pellets of the copepod Acartia tonsa. Mar Ecol Prog Ser 175:87-96

Fowler SW, Fisher NS (1983) Viability of marine phytoplankton in zooplankton fecal pellets. Deep-Sea Res A 30:963-969

Fransz HG, Colebrook JM, Gamble JC, Krause M (1991) The zooplankton of the North Sea. Neth J Sea Res 28: $1-52$

> Frigeri LG, Radabaugh TR, Haynes PA, Hildebrand M (2006) Identification of proteins from a cell wall fraction of the diatom Thalassiosira pseudonana: insights into silica structure formation. Mol Cell Proteomics 5:182-193

Fuhrmann T, Landwehr S, El Rharbi-Kucki M, Sumper M (2004) Diatoms as living photonic crystals. Appl Phys B 78:257-260

González HE, Smetacek V (1994) The possible role of the cyclopoid copepod Oithona in retarding vertical flux of zooplankton faecal material. Mar Ecol Prog Ser 113: 233-246

Guillard RRL, Ryther JH (1962) Studies of marine planktonic diatoms. I. Cyclotella Nana Hustedt and Detonula Confervacea (Ceve) Gran. Can J Microbiol 8:229-239

Hale MS, Mitchell JG (2001) Functional morphology of diatom frustule microstructures: hydrodynamic control of Brownian particle diffusion and advection. Aquat Microb Ecol 24:287-295

> Halsband C, Hirche HJ (2001) Reproductive cycles of dominant calanoid copepods in the North Sea. Mar Ecol Prog Ser 209:219-229

Halsband-Lenk C, Carlotti F, Greve W (2004) Life-history strategies of calanoid congeners under two different climate regimes: a comparison. ICES J Mar Sci 61:709-720

Hamm CE (2005) The evolution of advanced mechanical defenses and potential technological applications of diatom shells. J Nanosci Nanotechnol 5:108-119

Hamm C, Smetacek V (2007) Armor: why, when and how? In: Falkowski PG, Knoll AH (eds) Evolution of primary producers in the sea. Academic Press, Burlington, MA, p 311-332

> Hamm CE, Merkel R, Springer O, Jurkojc P, Maier C, Prechtel K, Smetacek V (2003) Architecture and material properties of diatom shells provide effective mechanical protection. Nature 421:841-843

> Hanley ME, Lamont BB, Fairbanks MM, Rafferty CM (2007) Plant structural traits and their role in anti-herbivore defence. Perspect Plant Ecol Evol Syst 8:157-178

> Hay ME, Fenical W (1988) Marine plant-herbivore interactions: the ecology of chemical defense. Annu Rev Ecol Syst 19:111-145

> Herms DA, Mattson WJ (1992) The dilemma of plants: to grow or defend. Q Rev Biol 67:283-335
Hickel W (1975) The mesozooplankton in the Wadden Sea of Sylt (North Sea). Helgol Mar Res 27:254-262

Ianora A, Miralto A, Poulet SA, Carotenuto Y and others (2004) Aldehyde suppression of copepod recruitment in blooms of a ubiquitous planktonic diatom. Nature 429: 403-407

Itoh K (1970) A consideration on feeding habits of planktonic copepods in relation to the structure of their oral parts. Bull Plankton Soc Japan 17:1-10

> Jansen S (2008) Copepods grazing on Coscinodiscus wailesii: a question of size? Helgol Mar Res 62:251-255

> Jansen S, Bathmann U (2007) Algae viability within copepod faecal pellets: evidence from microscopic examinations. Mar Ecol Prog Ser 337:145-153

Katechakis A, Stibor H, Sommer U, Hansen T (2004) Feeding selectivities and food niche separation of Acartia clausi, Penilia avirostris (Crustacea) and Doliolum denticulatum (Thaliacea) in Blanes Bay (Catalan Sea, NW Mediterranean). J Plankton Res 26: 589-603

Kiørboe T, Møhlenberg F, Nicolajsen H (1982) Ingestion rate and gut clearance in the planktonic copepod Centropages hamatus (Lilljeborg) in relation to food concentration and temperature. Ophelia 21:181-194

Kiørboe T, Saiz E, Viitasalo M (1996) Prey switching behaviour in the planktonic copepod Acartia tonsa. Mar Ecol Prog Ser 143:65-75

Kirschtel DB (1996) BIOVOL, Ver. 2.1. Available at: http:// www.msu.edu/ kirschte/biovol/index.html (accessed 20 September 2012)

Kleppel GS (1993) On the diet of calanoid copepods. Mar Ecol Prog Ser 99:183-195

> Koehl MAR (2004) Biomechanics of microscopic appendages: functional shifts caused by changes in speed. J Biomech 37:789-795

- Komar PD, Morse AP, Small LF, Fowler SW (1981) An analysis of sinking rates of natural copepod and euphausiid fecal pellets. Limnol Oceanogr 26:172-180

Koski M, Klein Breteler WCM (2003) Influence of diet on copepod survival in the laboratory. Mar Ecol Prog Ser 264:73-82

Kühn SF (1997) Rhizamoeba schnepfii sp. nov., a naked amoeba feeding on marine diatoms (North Sea, German Bight). Arch Protistenkd 147:277-282

$>$ Kuwata A, Tsuda A (2005) Selection and viability after ingestion of vegetative cells, resting spores and resting cells of the marine diatom, Chaetoceros pseudocurvisetus, by two copepods. J Exp Mar Biol Ecol 322: $143-151$

> Laland KN, Boogert NJ (2010) Niche construction, co-evolution and biodiversity. Ecol Econ 69:731-736

Laland KN, Odling-Smee FJ, Feldman MW (1999) Evolutionary consequences of niche construction and their implications for ecology. Proc Natl Acad Sci USA 96: 10242-10247

> Malkiel E, Sheng J, Katz J, Strickler JR (2003) The threedimensional flow field generated by a feeding calanoid copepod measured using digital holography. J Exp Biol 206:3657-3666

> Mann DG (1999) The species concept in diatoms. Phycologia 38:437-495

Masateru A, Omori M (1963) Preliminary survey of the relationship between the feeding habit and the structure of the mouth-parts of marine copepods. Limnol Oceanogr 8: $116-126$ 
Mayzaud P, Tirelli V, Bernard JM, Roche-Mayzaud O (1998) The influence of food quality on the nutritional acclimation of the copepod Acartia clausi. J Mar Syst 15:483-493

Michels J, Schnack-Schiel SB (2005) Feeding in dominant Antarctic copepods - Does the morphology of the mandibular gnathobases relate to diet? Mar Biol 146:483-495

Michels J, Vogt J, Gorb SN (2012) Tools for crushing diatoms - opal teeth in copepods feature a rubber-like bearing composed of resilin. Sci Rep 2:1-6

Moerschbacher B, Mendgen K (2000) Structural aspects of defense. Universität Konstanz, Konstanz

Møller EF (2005) Sloppy feeding in marine copepods: preysize-dependent production of dissolved organic carbon. J Plankton Res 27:27-35

Møller EF, Nielsen TG (2001) Production of bacterial substrate by marine copepods: effect of phytoplankton biomass and cell size. J Plankton Res 23:527-536

Paffenhöfer GA (1971) Grazing and ingestion rates of nauplii, copepodids and adults of the marine planktonic copepod Calanus helgolandicus. Mar Biol 11:286-298

Paffenhofer GA (1976) Feeding, growth, and food conversion of the marine planktonic copepod Calanus helgolandicus. Limnol Oceanogr 21:39-50

Paffenhöfer GA (2002) An assessment of the effects of diatoms on planktonic copepods. Mar Ecol Prog Ser 227: 305-310

Paffenhöfer GA, Van Sant KB (1985) The feeding response of a marine planktonic copepod to quantity and quality of particles. Mar Ecol Prog Ser 27:55-65

Pagano M, Kouassi E, Saint-Jean L, Arfi R, Bouvy M (2003) Feeding of Acartia clausi and Pseudodiaptomus hessei (Copepoda: Calanoida) on natural particles in a tropical lagoon (Ebrié, Côte d'Ivoire). Estuar Coast Shelf Sci 56: 433-445

Pearson PN (2001) Red queen hypothesis. John Wiley \& Sons, London

Pohnert G (2000) Wound-activated chemical defense in unicellular planktonic algae. Angew Chem Int Ed 39: 4352-4354

Rausher MD (2001) Co-evolution and plant resistance to natural enemies. Nature 411:857-864

Round F, Crawford R, Mann D (1990) The diatoms - Biology and morphology of the genera. Cambridge University Press, Cambridge

Roy S, Harris RP, Poulet SA (1989) Inefficient feeding by Calanus helgolandicus and Temora longicornis on Coscinodiscus wailesii: quantitative estimation using chlorophyll-type pigments and effects on dissolved free amino acids. Mar Ecol Prog Ser 52:145-153

Schnack SB (1989) Functional morphology of feeding appendages in calanoid copepods. In: Felgenhauer BE, Watling L, Thistle AB (eds) Functional morphology of

Editorial responsibility: Anna Pasternak, Moscow, Russian Federation feeding and grooming in Crustacea. Balkema, Rotterdam, p 137-151

Small LF, Fowler SW, Ünlü MY (1979) Sinking rates of natural copepod fecal pellets. Mar Biol 51:233-241

> Smetacek V (1999) Diatoms and the ocean carbon cycle. Protist 150:25-32

- Smetacek V (2001) A watery arms race. Nature 411:745-745

- Stenseth NC, Smith JM (1984) Coevolution in ecosystems: red queen evolution or stasis? Evolution 38:870-880

Storch O, Pfisterer O (1925) Der Fangapparat von Diaptomus. J Comp Physiol A Neuroethol Sens Neural Behav Physiol 3:330-376

Strathmann RR (1967) Estimating the organic carbon content of phytoplankton from cell volume or plasma volume. Limnol Oceanogr 12:411-418

Sullivan BK, Miller CB, Peterson WT, Soeldner AH (1975) A scanning electron microscope study of the mandibular morphology of boreal copepods. Mar Biol 30:175-182

Sumper M, Brunner E (2008) Silica biomineralisation in diatoms: the model organism Thalassiosira pseudonana. ChemBioChem 9:1187-1194

Sumper M, Kröger N (2004) Silica formation in diatoms: the function of long-chain polyamines and silaffins. J Mater Chem 14:2059-2065

Suzuki R, Arita T (2005) How niche construction can guide coevolution. In: Capcarrère $M$, Freitas $A$, Bentley $P$, Johnson C, Timmis J (eds) Advances in artificial life. Lecture Notes in Computer Science, Vol 3630. Springer, Heidelberg, p 373-382

Turner JT (1978) Scanning electron microscope investigations of feeding habits and mouthpart structures of three species of copepods of the family Pontellidae. Bull Mar Sci 28:487-500

Turner JT, Ferrante JG (1979) Zooplankton fecal pellets in aquatic ecosystems. Bioscience 29:670-677

van Alstyne KL, Wolfe GV, Freidenburg TL, Neill A, Hicken C (2001) Activated defense systems in marine macroalgae: evidence for an ecological role for DMSP cleavage. Mar Ecol Prog Ser 213:53-65

van Valen L (1973) A new evolutionary law. Evol Theory 1: $1-30$

Vidal J (1980) Physioecology of zooplankton. I. Effects of phytoplankton concentration, temperature, and body size on the growth rate of Calanus pacificus and Pseudocalanus sp. Mar Biol 56:111-134

Wolfe GV (2000) The chemical defense ecology of marine unicellular plankton: constraints, mechanisms, and impacts. Biol Bull 198:225-244

Wright JT, de Nys R, Poore AGB, Steinberg PD (2004) Chemical defense in a marine alga: heritability and the potential for selection by herbivores. Ecology 85: 2946-2959

Submitted: May 25, 2012; Accepted: December 14, 2012 Proofs received from author(s): April 8, 2013 